NBER WORKING PAPER SERIES

\title{
DOES ENTRY REGULATION HINDER JOB CREATION? EVIDENCE FROM THE FRENCH RETAIL INDUSTRY
}

\author{
Marianne Bertrand \\ Francis Kramarz \\ Working Paper 8211 \\ http://www.nber.org/papers/w8211 \\ NATIONAL BUREAU OF ECONOMIC RESEARCH \\ 1050 Massachusetts Avenue \\ Cambridge, MA 02138 \\ April 2001
}

We thank C. Couton, P. Jault, J.C. Martin, C. Lefèvre, B. Levy, J. Chiche, E. Renard, S. Haller and B. Vatré for giving us access to the various databases used in this paper. We are grateful to Daron Acemoglu, Joe Altonji, Jon Gruber, Larry Katz, Sendhil Mullainathan, Sam Peltzman, Jan Van Ours and to participants at the NBER Labor Studies Meeting (Surnmer 2000), the CEPR Labor Studies Meeting (Fall 2000), Northwestern University, CREST and University of Zurich for very helpful comments. The views expressed herein are those of the authors and not necessarily those of the National Bureau of Economic Research.

(C) 2001 by Marianne Bertrand and Francis Kramarz. All rights reserved. Short sections of text, not to exceed two paragraphs, may be quoted without explicit permission provided that full credit, including (C) notice, is given to the source. 
Does Entry Regulation Hinder Job Creation? Evidence from the French Retail Industry Marianne Bertrand and Francis Kramarz

NBER Working Paper No. 8211

April 2001

JEL No. J0, L5

\begin{abstract}
Does entry regulation hinder job creation? We investigate this question in the context of the French retail industry, a sector that has experienced especially low rates of job creation over the last 25 years. Since the early 70s, the French government has required regional zoning board approval for the creation or extension of any large retail store. Using a unique database that provides time and regional variation in boards' approval decisions, we show that this requirement created barriers to entry in the retail sector. We also show that these barriers to entry, either measured directly by approval rates or predicted by the political composition of the boards, weakened employment growth in the retail industry. Our findings indicate that retail employment could have been more than 10\% higher today had entry regulation not been introduced. Promoting product market competition may thus be a key reform for countries with poor employment performance.
\end{abstract}

Marianne Bertrand

Graduate School of Business

University of Chicago,

NBER and CEPR

marianne.bertrand@gsb.uchicago.edu
Francis Kramarz

CREST and CEPR

kramarz@ensae.fr 


\section{Introduction}

Does entry regulation hinder job creation? This is a question of interest to all developed and developing nations fighting sluggish rates of employment growth. Consider Europe. Most casual observers blame labor market institutions for the employment crisis that has plagued Europe since the mid-seventies and stress the need for reform. Yet, empirically validating the commonly held belief that rigid employment protection systems, generous levels of unemployment benefits, high minimum wages and high tax wedges have been the barriers to faster job creation is enormously challenging. Some researchers have gone so far as to reject the idea that labor market regulations can directly explain the European employment problem (Blanchard and Wolfers, 1999). As these authors note, labor market constraints in Europe pre-date the rise in unemployment and have been trending mostly downwards over a period of steadily rising unemployment. Moreover, Card, Kramarz and Lemieux (1996) have rejected the other popular idea that the interaction of these pre-existing labor market regulations with a global wave of skill-biased technological changes can explain the job crisis. ${ }^{1}$ Because the case against labor market institutions is at best inconclusive so far, the door is left wide open for alternative explanations of the lengthy depression in European labor markets.

The simple observation at the basis of this research is that many of the nations with poor employment performance do not only distinguish themselves from better performers such as the US through their regulatory practices on the labor market side, but also through restraints on entry and competition on the product market side. Consider Europe again. Djankov, La Porta, Lopez de Silanes and Shleifer (2000) document the multiple, costly and time-consuming legal requirements for starting a new business in many European countries. The McKinsey Global Institute $(1994,1997)$ emphasizes

\footnotetext{
${ }^{1}$ In their cross-country study, Blanchard and Wolfers (1999) lend more credence to the interaction story, suggesting that macroeconomic shocks might have been especially important.
} 
in various reports on Europe the high level of product market restrictions in sectors such as services, construction and banking. Our goal in this paper is to systematically investigate whether measures to block entry and limit competition in product markets play a substantial role in explaining low rates of job creation.

The possibility of a link between entry regulation and job creation rests on straightforward theoretical arguments. From an imperfect competition perspective, the regulation of entry in an industry increases incumbents'market power, leading to higher markups, lower product demand and lower equilibrium employment. ${ }^{2}$ In a related fashion, older disequilibrium models where prices are exogeneously fixed above competitive equilibrium level, such as Barro and Grossman (1971), also predict that employment will be reduced because of the constrained product demand. This price mechanism is the most obvious and general channel through which entry regulation can be tied to employment outcomes; more industry specific channels may also exist. Consider the retail industry, the sector we will focus on in this paper. First, the product differentiation that occurs as competition strengthens in retail trade often leads to the development of higher value, more labor intensive, stores. In the US food retail sector for example, high quality chains have been developing in parallel with lower quality ones. Because the high quality chains compete less on prices but more on the multiple services they provide to customers, they are typically more labor-intensive. Second, some authors have noted the importance of positive spillover effects in retail trade, whereby the creation of a large anchor store induces enough customer traffic to encourage the creation of additional stores and additional jobs. Entry regulation measures that restrains the creation of large retail spaces and large anchor stores will prevent such positive spillover effects from occurring. ${ }^{3}$ Finally, the regulation of entry in a service sector such as re-

\footnotetext{
${ }^{2}$ See Blanchard and Giavazzi (2001) for a macroeconomic model of the effects of product market regulations on labor market outcomes.

${ }^{3}$ Using evidence on rents paid by anchors and non-anchor stores in US shopping malls, Pashigian (1998) shows that the positive externalities created by anchor stores are quite substantial.
} 
tail trade may lead to trading off employment time for customers' time. Limiting the number of stores forces customers to face longer commuting time to the closest supermarket and longer waiting times once inside the store. In other words, with less stores available to shop at, customers' time becomes a more important input in the retail industry production function and operates as a substitute for retail employment.

Despite these multiple theoretical arguments, there has been so far a dearth of systematic empirical work examining the impact of entry and product market regulation on job creation. ${ }^{4}$ In this paper, we perform such a work for France. We focus on what might have been the most important governmental rule to prevent entry in the French retail trade sector: commercial zoning.

Introduced at the end of 1973, the "Loi D'Orientation du Commerce et de l'Artisanat", also called the "Loi Royer," was originally motivated by a desire to protect small retail stores from the "unruly growth of new forms of distribution" (Mission d'Information de la Direction Génerale du Commerce Intérieur et des Prix, 1974). Prior to the introduction of the Loi Royer, starting a new store in France only required obtaining a license to build. Starting in 1974, the creation of any new large store or the extension of an existing store had to be approved by a regional board ("commission départementale") composed of store owners, craftsmen, consumers and regionally elected politicians. Amended several times over the last two decades, the "Loi Royer" is still in place today and constitutes a binding constraint on the creation of new retail space. Between 1974 and 1998, zoning boards approved only about $40 \%$ of the applications for openings of new stores or extensions of existing stores.

While our study focuses on France, such commercial zoning laws are common in many other European countries. The study performed by the McKinsey Global Institute in 1994 shows that Germany,

\footnotetext{
${ }^{4}$ Only a few authors, such as Krueger and Pischke (1997), Gersbach (2000) and Aghion (1999), have previously mentioned the importance of this alternative explanation to Europe's employment crisis. In a related paper, Nickell and Layard (1999) advocate promoting product market competition in Europe in order to eliminate the negative employment effects of trade unions.
} 
Italy and Spain all have adopted some forms of commercial zoning regulations. ${ }^{5}$ One major advantage of focusing on the French experience is that while zoning is administered at the regional level in France, most other governmental or legal decisions are centralized in Paris. Hence, regional governments have only very limited means to encourage or discourage business formation other than through the zoning boards.

We exploit a unique database that reports detailed information on the entire universe of applications for store creations and extensions considered by every French département between 1975 and $1998 .^{6}$ For most of the applications, we know the size of the store, whether the store was in food or non-food retail, the brand name of the store promoter and whether the application was approved or not by the board. After aggregating this detailed information into département/year cells, we match it to standard labor force survey extracts in order to study employment effects.

We show that increases in the fraction of approved stores in a département increase retail employment in that département. This is true even after we control for the number of applications to capture time and region specific variation in retail business opportunities. Our findings suggest that a département with an average approval rate could have at least $10 \%$ more retail employment today had entry regulation not been introduced. The effects appear quantitatively stronger in food retail than in non-food retail. Not surprisingly, we show that the fraction of people working in small retail establishments drops as more large stores are allowed to enter. We also show that part-time work in retail trade increases as the zoning boards accept more applications.

We perform various tests of the robustness of these results. We show that future approval rates in a département do not affect current retail employment in that département. We also account in multiple

\footnotetext{
${ }^{5}$ Moreover, related restrictions to opening hours exist in almost all European countries (MGI, 1994).

${ }^{6}$ There are 95 different départements in France. In this paper, the words "département" and "region" are meant to describe the same geographic unit. Each département or region has its own zoning board.
} 
ways for the possibility that other factors (such as policy changes or economic shocks) may be affecting retail employment in a region and at the same be correlated with the stringency of entry regulation. ${ }^{7}$ First, we show that not only the level but also the fraction of employment in retail trade is affected by entry regulation. This indicates that our measure of entry regulation is unlikely to proxy for other general economic or policy changes in the region. Second, we investigate whether the zoning regulation also affects employment in another industrial with a comparable fraction of low wage workers: hotels and restaurants. We find no significant effect of the zoning regulation on employment in hotels and restaurants. This further indicates that our measure of entry regulation is unlikely to capture other regional policies targeting the less skilled.

We also address the possibility that applications are endogenous to the expected stringency of the zoning boards. If applications are costly to submit, one might expect a lower application rate whenever the board is expected to turn down more projects. This may bias our estimates of the effect of approval rates on retail employment. For example, a high approval rate may correspond to a situation where only a selected set of promoters with a probability of being approved apply for entry. In response, we propose an alternative estimation strategy that does not directly rely on applications. We instrument authorizations in a département with the political representation in that département. Right-wing parties, which are known to receive the political support of the self-employed, are likely to more strongly oppose the entry of new retail units in order to protect mom-and-pop store owners. ${ }^{8}$ Moreover, political parties can directly affect the level of entry in retail as an elected politician is often the median voter on the regional zoning boards. We show that increases in the political representation of right-wing parties in a region are indeed associated with a slower rate of entry. We also show that

\footnotetext{
${ }^{7}$ As we already mentioned, French départements only have limited policy discretion, which already weakens the concern of omitted regional policy changes.

${ }^{8}$ This feature of the retail industry is especially interesting. Indeed, we typically expect right-wing parties to be the ones adopting relatively fewer regulatory measures, either in product or labor markets.
} 
such politically induced barriers to entry slow down employment growth in the retail industry. The magnitude of the entry regulation effect appears even stronger under this instrumentation strategy.

The rest of this paper is organized as follows. In section 2, we briefly review long-term and more recent employment trends in the retail industry versus other low-wage industries in France. We show that employment growth over the last 25 years has been especially sluggish in retail trade compared to other low-wage sectors. Section 3 describes the Loi Royer in further detail. In that section, we show that the Loi Royer did have bite and created a real barrier to the creation of new retail space. We also present some evidence that the Loi Royer served in part as a way to limit competition between large store chains. Section 4 contains our basic empirical study of the employment effects of entry regulation. Section 5 investigates the role played by politicians in the entry regulation process and develops an instrumentation strategy around it. We summarize and discuss future extensions in section 6 . The different data sources are discussed in detail in section A1.

\section{Employment Trends in Retail Trade and Other Law Wage Sectors}

We borrow Table 1 from Piketty (1997). This table documents comparative long-term employment trends for the US and France, focusing on two economic sectors: retail and wholesale trade, and hotels and restaurants. As Piketty already noted, the fraction of total employment in these two sectors is much smaller in France than it is in the US. In 1996, retail and wholesale trade accounted for $13.6 \%$ of total employment in France and $17.5 \%$ of total employment in the US. In the same year, $3.5 \%$ of French workers were working in hotels and restaurants compared to $6.6 \%$ of US workers.

One natural interpretation of such differences, and the one favored by Piketty, is that they reflect the disruptive effect of various labor market regulations. Both retail and wholesale trade and hotels and 
restaurants are sectors that employ a large fraction of low skilled workers. These sectors are therefore more likely to suffer from a set of rules, such as minimum wage laws, that have increased the relative cost of hiring workers from the bottom part of the skill distribution. Piketty concludes that the fact that France is "missing jobs" in those specific sectors bolsters the case for labor market reforms in France.

Table 1 offers some other interesting insights. In France, the fraction of employment in wholesale and retail trade seems to have grown until the early $70 \mathrm{~s}$ but has since then stagnated. In contrast, although the fraction of workers in hotels and restaurants did not change between 1973 and 1982 in France, the last two decades have witnessed strictly positive growth in that sector. This is striking in comparison to the stagnation in retail and wholesale trade. While both sectors were exposed to potentially disruptive labor market regulations, job creation in retail and wholesale trade seems to have suffered the most over the last two decades.

In Table 2, we compare employment trends in retail trade, hotels and restaurants, and other low wage services within French départements between 1975 and $1998 .{ }^{9}$ Unlike Piketty, we focus on retail trade in order to isolate the specific industrial sector that has been affected by the commercial zoning law. The dependent variables are employment share (Panel A) and log(employment) (Panel B) in retail (column 1), food retail (column 2), non food retail (column 3), hotels and restaurants (column 4) and other low-wage services (column 5). Each regression in Table 2 includes, in addition to a time trend and a constant, département fixed effects to account for differences in industrial composition across regions in France. We also weight each observation by the total population in that département/year cell.

While the fraction of employment in the entire (wholesale and retail) trade sector has roughly

\footnotetext{
${ }^{9}$ The Labor Force data used here is described in section A1.
} 
stagnated between 73 and 96 (Table 1), we find that the fraction of employment in retail has in fact been strictly declining on average every year between 75 and 98. Like Piketty (1997), we find that the fraction of employment in hotels and restaurants grew on average every year over the same time period. The fraction of employment in other low wage services grew even more rapidly. While retail employment grew at an average annual rate of a quarter of a percent, employment in hotels and restaurants grew at an annual rate of more than one percent. Obviously, these diverging trends might simply reflect structural differences between these industries. Nevertheless, they also suggest that regulatory factors other than labor market institutions may have especially hindered job creation in the retail sector over that period. In the rest of this paper, we study whether the Loi Royer was one such factor.

\section{Entry Regulation}

\subsection{La Loi Royer}

In December 1973, the French parliament adopted the "Loi d'Orientation du Commerce et de l'Artisanat," commonly known as the "Loi Royer" (Ministère de l'Industrie, du Commerce et de l'Artisanat, 1974). The original spirit of this legislative change was to protect small shopkeepers and craftsmen in the face of a rapidly evolving large distribution market. ${ }^{10}$ The law proposed to achieve that goal through various measures. Some of these measures were implemented at the national level. For example, one component of the law was to establish more fiscal equity between salaried and self-employed. The law also set up funds for financial assistance to old-aged shopkeepers and craftsmen. Such centralized reforms are difficult to study empirically as they cannot easily be separated from other policy or economic changes. In this paper, we focus on the only component of the law that was implemented at the

\footnotetext{
${ }^{10}$ In France, butchers and bakers are considered "craftsmen of the mouth."
} 
regional level: the commercial zoning regulation.

Before the introduction of the Loi Royer, opening a large store in France only required obtaining a license to build. As in the US, environmental and urban design considerations are the major criteria behind the granting of a license to build. While town planning imposes important constraints on the exact location of a new store, it does not seriously limit the number of stores created. Starting in 1974, however, the construction of a new large store had to be approved by a regional board called the "Commission Départementale d'Urbanisme Commercial." Any new store with a sales area of more than 1,500 square meters fell under the law. In cities of less than 40,000 people, the law applied to any new store of more than 1,000 square meters. In addition, in all areas, any substantial extension of an existing store also had to be approved. In case of refusal by the regional board, a promoter had the opportunity to appeal the decision to the national Minister in charge of retail and craft. The Minister, advised by a national zoning commission called "Commission Nationale d'Urbanisme Commercial," had the power to overturn the decision of the regional commission. ${ }^{11}$

The composition of the regional boards is also heavily regulated. It must include twenty voting members. Nine of these must be shopkeepers and craftsmen's representatives. Seven of these nine members must be self-employed. Two members represent consumers' interests. ${ }^{12}$ The last nine members are locally elected politicians, mostly city mayors. A new retail establishment must not be rejected by more than half plus one of the members present to get approved. Because consumer representatives almost always vote in favor of the new store, the median voter on these boards tends to be an elected politician. We exploit this fact later on as part of our identification strategy.

\footnotetext{
${ }^{11}$ While our data covers the whole universe of applications to the regional boards, we have only limited information on the number of appeals occurring at the national level and on the results of these appeals. The only data we have cover the period 94 to 97 . That data suggest that appeals are rarely successful. Only about on average $10 \%$ of the new stores are authorized at the national level during that period.

${ }^{12}$ Interestingly, consumer representatives are said to almost always favor the approval of a new retail unit.
} 
The Loi Royer is still in place today. It has been amended in several ways, all tending to increase its stringency. This has been primarily achieved by reducing the size thresholds and strengthening the majority requirement for approval. ${ }^{13}$

\subsection{Did the Loi Royer Create a Barrier to Entry?}

A priori, the Loi Royer could just be another piece of legislation, adopted as a political move to appease small store owners but without any real bite. We use a unique database from the "Direction du Commerce et de l'Artisanat" (DECAS) to directly assess whether the Loi Royer did in fact create a real barrier to entry in the retail industry. ${ }^{14}$ The DECAS, a branch of the Ministry of Economics and Finance, has maintained an exhaustive listing of all applications submitted to any zoning board since the inception of the Loi Royer. For almost every application, DECAS records the name of the applicant, size of the store (in square meters), specialty of the store (food or non-food with varying details depending on the year), the location of the store (département and city), terms of the application (whether seeking to create or expand a previously existing store), and the outcome of the commission vote (an indicator for whether the store was authorized or rejected, as well as the number of "yes" votes, number of "no" votes, and number of abstentions).

The DECAS data shows that, since its inception, the Loi Royer prevented the creation of a massive number of retail establishments. Simple tabulations show that on average about $70 \%$ of all applications (in square meters) for new food retail units are turned down each year. In non-food retail, about $55 \%$ of all prospective promoters see their projects rejected each year. ${ }^{15}$

\footnotetext{
${ }^{13}$ Unfortunately, most of the amendments occurred towards the end of our sample period, making it difficult to incorporate them into our identification strategy.

${ }^{14}$ The DECAS data is presented in further detail in section A1.

${ }^{15}$ The fraction of approvals has been trending up over time, possibly because these low approval rates earlier on discouraged future applicants. This raises the issue of the possible endogeneity of applications, which we address in section 5 .
} 
Table 3 provides additional evidence on how binding the commercial zoning regulation has been. Table 3 summarizes the distribution of applications and authorizations by city in food retail from the introduction of the law until 1998. Over that time period, the zoning boards evaluated slightly more than 8,000 applications in about 2800 different cities. While at least 3 applications have been submitted in $25 \%$ of those cities over that time period, only about $5 \%$ of the cities end up with 3 stores or more. While more than $55 \%$ of the cities recorded more than one application, nearly $75 \%$ of them end up with at best one authorization. In fact, more than a quarter of the cities applying end up without any authorization at all. ${ }^{16}$

\subsection{Did the Loi Royer Increase Retailers' Concentration?}

Supermarkets and megastores in France operate in a rather concentrated market environment. ${ }^{17}$ In 1997, the sales of the top 5 chains represented $31 \%$ of total sales in the retail industry (Dobson and Waterson, 2000, Table 3). ${ }^{18}$ In food retail, the market share of the top 5 retailers increased from 42 to $52 \%$ between 1988 and 1996 . As a comparison, the market share of the top five food retailers in the UK, which has the most concentrated retail industry in Europe, went from 53 to $64 \%$ over the same time period. Such product market concentration is also correlated with higher price indices. In August 1998, the price of a similar basket of goods was 100 in the UK, 74 in France, 65 in Germany, 62 in Belgium and 61 in the Netherlands (id., Table 1).

It has been anecdotally suggested that the Loi Royer, under the guise of protecting small shopkeepers, was de facto used to limit product market competition among large retail chains and might thus

\footnotetext{
${ }^{16}$ Note that we do not know the number of large stores in place in each city prior to the introduction of the zoning law in 1974.

${ }^{17} \mathrm{~A}$ megastore is defined as any store with over 2,500 square meters of space. A supermarket is defined as any store with between 400 and 2,500 square meters of space.

${ }^{18}$ This fraction varies widely among European countries, from $11 \%$ in Greece or Italy to $66 \%$ in Sweden and $72 \%$ in Finland (Dobson and Waterson, 2000).
} 
have played a non-negligible role in the development of such a concentrated retail sector in France. ${ }^{19}$ More specifically, incumbent store promoters are said to exert influence on the zoning boards to restrain the entry of competing chains and thereby protect their local market power. ${ }^{20}$

This anecdotal evidence is confirmed by our findings in Table 4. For this table, we focus again on food retail. Moreover, we focus on cases involving a prospective promoter's application to a regional zoning board in a city where one supermarket or megastore has already been approved. There are about 2700 such episodes in our micro data. We ask whether the probability of the new store being approved is lower when the new store has a different brand name than the incumbent store. ${ }^{21}$

In column 1 of Table 4, we use the share of yes votes as a dependent variable. All regressions control for the brand name of the incumbent, the brand name of the applicant, the size of the prospective store (in log square meters), the stock of pre-authorized stores (also in log square meters), year dummies and département dummies. We also control for whether the application relates to the extension of an existing store or the creation of a new store. The control variable of specific interest to us is a dummy variable that equals 1 if the incumbent and the applicant share the same brand name, 0 otherwise.

We find that the coefficient on that dummy variable is positive (.046) and statistically significant. In other words, if the applicant and incumbent do not belong to the same chain, the fraction of yes votes for the applicant's project goes down by $4.6 \%$. As an interesting aside, note also that the share of yes votes significantly goes down with the size of the application. Hence, larger projects are less

\footnotetext{
${ }^{19}$ In 1967 , there were about 520,000 different firms in the retail industry, including specialty stores (Insee, 1967). By 1997, that number was down to slightly less than 400,000 (Insee, 2000). The fraction of small retail shops in France, while it has been declining, has stayed very high. While around four fifths of all firms in 1967 had strictly fewer than 3 employees, that fraction was about three-quarters in 1997. At the same time, supermarkets and megastores have extended their presence in France, as they have in other European countries. Megastores' market share went from $3.6 \%$ in 1970 to $33 \%$ in 1997. Supermarkets' market share went from $9 \%$ to $28.3 \%$ (Allain and Chambolle, 1999, Table 1).

${ }^{20}$ Personal conversion, DECAS. Remember that representatives of the local supermarkets are also appointed to the zoning boards.

${ }^{21}$ As already mentioned, our data does not allow us to account for any incumbent supermarket or megastore created prior to the introduction of the Loi Royer.
} 
likely to be approved by zoning boards. We replicate the same exercise in column 2 but now use as the dependent variable a dummy variable that equals 1 if the project is approved, 0 otherwise. The result goes through even though it is less precisely estimated. The probability of approval goes up by about $4.6 \%$ when incumbent and applicant share the same brand name. ${ }^{22}$

In summary, the evidence presented in this section suggests that the Loi Royer constituted a real barrier to entry in retail trade. Moreover, the data suggests that the Loi Royer led to selective entry that fostered retailers' concentration. In the introduction, we discussed several theoretical channels through which such an apparent constraint to entry or product market competition can hinder job creation. In the next section, we directly investigate whether the Loi Royer can help explain, at least in part, the low rate of job creation in the French retail sector.

\section{Employment Effects of Entry Regulation}

\subsection{Empirical Methodology}

In order to empirically assess the impact of entry regulation on job creation in the retail industry, one could simply ask whether increases in the stock of authorized retail space in a given département positively affect retail employment in that département. One problem with such a simple approach is that variation in authorizations could be driven by economic factors and may not only reflect the relative leniency of different regional zoning boards. For example, the stock of authorizations may increase more rapidly when the retail industry is in a cyclical upturn and more applications are submitted to the

\footnotetext{
${ }^{22}$ Bertrand et al. (2000) present complementary evidence on retail prices and industry concentration in France. In that paper, we study whether retail prices for a set of elementary food and non-food items are affected both by the number of large stores and the degree of chain concentration in a city. We find that the presence of more megastores or supermarkets in a city has a large negative impact on prices in all retail stores in the area. The entry of a new megastore has an especially strong negative impact on average retail prices. We also find some evidence of collusive price behavior between megastores of the same brandname. This later effect is especially important within smaller cities.
} 
boards. In that case, an increase in the stock of authorizations could be positively correlated with an increase in the rest of the retail capital stock, a factor we do not measure directly and yet clearly influences retail employment. No new authorization in a given département in a given year may not mean that entry was severely regulated in that year but rather that the economic environment was very bad in that département in that year.

As this discussion makes clear, a careful investigation of the effect of entry regulation will require adequate control for variations in the quality of the economic environment for retail businesses. Fortunately, the DECAS data allows us to deal with this difficulty. Indeed, the DECAS data contains information on every application submitted to the regional zoning boards, whether the application was approved or not. A better economic environment for retail businesses should be captured by a more rapid increase in the stock of applications, not authorizations. ${ }^{23}$ Therefore, we can control in the empirical model for both the stock of applications as well as the stock of authorizations. Alternatively, we can directly use the fraction of authorizations as our measure of zoning stringency, while also controlling for the stock of applications. We can ask whether retail employment grows more rapidly when a larger fraction of applications are approved by a zoning board. More specifically, we propose to estimate the two following regressions:

$$
\log \left(\text { retail } \mathrm{emp}_{i t}\right)=\theta_{1} \log \left(\text { authorization }_{i(t-4)}\right)+\theta_{2} \log \left(\operatorname{application}_{i(t-1)}\right)+\alpha_{i}+\beta_{t}+\gamma X_{i t}+\epsilon_{i t}
$$

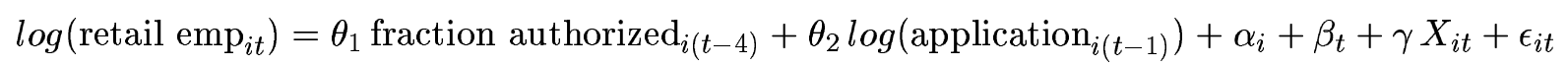

where retail $\mathrm{emp}_{i t}$ is employment in retail trade (total retail, food retail or non-food retail) in département $i$ and year $t$, authorization ${ }_{i(t-4)}$ is the stock of large (all, food or non-food) stores (in square meters)

\footnotetext{
${ }^{23} \mathrm{An}$ additional problem, however, is that applications could themselves be endogenous to the expected stringency of the zoning board and not only depend on economic conditions. We directly address this problem in section 5 .
} 
authorized in département $i$ up to year $t-4$, fraction authorized $_{i(t-4)}$ is the fraction of all applications that are approved in département $i$ up to year $t-4$, application $_{i(t-1)}$ is the stock of applications for large (all, food or non-food) stores (in square meters) submitted in département $i$ up to year $t-1, \alpha_{i}$ are département fixed effects, $\beta_{t}$ are year fixed effects and $X_{i t}$ is a vector of time-varying département characteristics. ${ }^{24}$

Based on conversations with members of DECAS, we lag both of the entry regulation variables, authorization $_{i(t-4)}$ and fraction authorized $_{i(t-4)}$, by four years in order to allow for a reasonable construction lag. Such a rather long delay accounts in part for the fact that any new promoter whose project is approved by a zoning board must still apply for a license to build before starting any construction. ${ }^{25}$

The vector of time-varying département characteristics $X_{i t}$ include the unemployment rate in the département, the age composition in the département (fraction below 21, fraction between 21 and 40, fraction between 41 and 60 and fraction above 60 ), as well as the urban/rural composition in the département (fraction living in rural areas, fraction living in small towns, fraction living in midsize towns, and fraction living in large towns). ${ }^{26}$ Finally, to make our results representative for the average French citizen, we weight each observation by the total population in that département/year cell.

Note that equations (1) and (2) include year dummies to account for aggregate time shocks. These year dummies will capture any aggregate economic shock but also any policy change at the central level that might affect retail employment. As we mentioned earlier, French départements have little discretion in setting their own policies. Importantly, départements have close to no autonomy in adopting their own labor market rules. Hence, the year dummies should adequately control for most other policy changes that may have occurred over the period under study. For example, any change in

\footnotetext{
${ }^{24}$ In some of the specifications, we will also use as a dependent variable the fraction of total employment in retail. We just justify this alternative dependent variable below.

${ }^{25}$ Our results are however robust to using slightly shorter construction lags.

${ }^{26}$ The exact construction of these variables is described in section A1.
} 
the minimum wage, which is set in Paris and applies uniformly to all départements, will be captured by the year dummies. ${ }^{27}$

Département fixed effects are also added as regressors in equations (1) and (2). They control for any fixed factor that might affect the level of retail employment in a given département. Such factors include the size of the département and the stock of retail capital (both large and small stores) that was in place prior to the introduction of the zoning law.

\subsection{Results}

The results of the estimation of these two basic regressions are reported in Tables 5, 6 and 7 . The data in all tables covers 95 départements over the period 1975 to 1998. In Table 5, we look at the entire retail sector. In Tables 6 and 7, we break the retail sector into its food and non-food components, respectively. We start by discussing Table 5. In Panel A, we use as a dependent variable the logarithm of retail employment. Column 1 shows that a 1 percent increase in the stock of authorized retail space leads to a .06 percent increase in retail employment. In column 2, we use the fraction of stores authorized since the inception of the law as the measure of entry regulation. We find that a 1 percentage point increase in the approval rate lead to a .16 percent increase in retail employment.

Columns 3 to 6 replicate columns 1 and 2 but try to account for the possible depreciation of the retail capital stock. In columns 3 and 4, we assume that stores that were authorized more than 15 years prior to $(t-4)$ have fully depreciated by time $t$. In columns 5 and 6 , we assume that stores that

\footnotetext{
${ }^{27}$ One decentralized policy that could potentially affect retail employment are local taxes. Most important for our purpose are taxes paid by businesses with establishments within a certain city ("taxe professionnelle"), taxes paid by building owners ("taxe foncière sur le bâti") and taxes paid by land owners ("taxe foncière sur le non-bâti"). Until 1981, départements had very little latitude in deciding either the nature or the level of these local taxes. Both rates and bases for those taxes were set at the national level prior to 1981. After 1981, rates for local taxes were decentralized but only to a certain degree. For example, tax rates are still subject to a national floor and a national ceiling. Moreover, the basis for each tax is still set at the national level. Finally, to the extent that tax changes may have a rather immediate impact on exit rates among existing retail businesses, they are not subject to the same implementation lag as entry regulation.
} 
were authorized more than 10 years prior to $(t-4)$ have fully depreciated by time $t$. We then compute the stock of authorized stores as well as approval rates based on these assumptions. This is a simple, even though admittedly crude, way to account for depreciation. In all cases, we find that less stringent entry regulation leads to faster job creation.

Are these effects economically large? What would be the effect of moving a département from an average authorization rate (about 40 percent) to the highest authorization rate (about 70 percent)? This would imply that, each year, the stock of authorized stores would grow on average by an extra 3,000 square meters, which is about a 4 percent increase in the 10-year stock of authorizations or a 3 percent increase in the non-depreciated stock of authorizations. This would in turn imply about a .2 percent increase in retail employment each year. ${ }^{28}$ Compounded over 25 years, a département with an average authorization rate could have increased its retail employment by nearly 5 percent by accepting 30 percent more applications on average each year. Moving from an average authorization rate of 40 percent to free entry (all applications are approved) would imply an extra 7 to 10 percent increase in the stock of authorizations each year. This would imply about a .5 percent annual increase in retail employment. Compounded over 25 years, this suggests that retail employment could be more than 10 percent higher today had entry regulation not been introduced. ${ }^{29}$

Panel B of Table 5 presents a first test of the robustness of our results. In this panel, we use as a dependent variable the fraction of total employment in retail instead of the logarithm of retail

\footnotetext{
${ }^{28}$ This seems like a reasonable order of magnitude. There are about 1 million 3 hundred thousands people working in the French retail sector, or about 14 thousands people on average by département. An extra 3,000 square meters represent about the size of a megastore. Megastores employ on average about 250 people.

${ }^{29}$ Clearly, the goal of these calculations is only to give a rough idea of the order of magnitude of the effect. These calculations suffer from various limitations. First, they are subject to the likely endogeneity of applications to the expected stringency of the zoning boards. It is possible that store promoters that would have entered in the absence of entry regulation do not even bother applying if they anticipate a high probability of rejection. This force will generate a downward bias in the estimated magnitude of effect. We investigate this problem in section 5 . On the other hand, it is possible that a promoter whose project got rejected by a given board try re-apply in a different département or in a different location within the same département. This force will generate an upward bias in the estimated magnitude of effect.
} 
employment. While we might expect the effect of entry regulation to feedback into other economic sectors, we still expect the effect to be strongest for retail employment. Therefore, we expect the fraction of employment in retail trade to increase with the ease of entry in the industry. If this were not true, one might worry that our entry regulation variables are capturing other economic or policy changes in the département. Panel B is otherwise organized exactly like Panel A. In all specifications, we find that authorizations and approval rates are both positively correlated with the fraction of total employment in the retail sector. A 1 percent increase in the stock of authorized stores lead to about a .003 percentage point increase in the fraction of employment in retail. A 1 percentage point increase in approval rates leads to about a .01 percentage point increase in the fraction of retail employment. In summary, the entry variables appear to capture some shocks that are specific to the retail industry.

Tables 6 and 7 replicate Table 5 but break down the retail sector into food (Table 6 ) and non-food (Table 7). Note that for retail food employment, we use the stocks of applications and authorizations in food retail only. Similarly, for non-food retail employment, we use the stocks of applications and authorizations in non-food retail only. Our basic findings of a negative relationship between retail employment and barriers to entry in retail hold true in both the food and non-food sectors. The results, however, appear quantitatively larger and statistically more robust in food retail than in nonfood retail.

Table 8 investigates the robustness of these basic results to various specification checks. We focus on the impact of entry regulation on the fraction of employment in retail (food plus non-food). In addition, we focus on the 15-year stock variables. Even columns use the stock of authorized stores as the measure of entry regulation; odd columns use the fraction of authorizations. In the first two columns, we address basic causality concerns by asking whether future variations in zoning stringency affect current retail employment. In column 1, we ask whether the stock of stores authorized as of $(t+1)$ affects the current 
fraction of retail employment after we control for the lagged stock of authorizations. In column 2, we ask whether the fraction of authorizations as of $(t+1)$ affects the current fraction of retail employment after we control for the lagged fraction of authorizations. In neither case do we find future entry variables affecting current employment. Columns 3 and 4 show that our findings are also robust to controlling for the one-year lagged fraction of retail employment. Columns 5 and 6 more explicitly investigate issues of persistence in both the employment variable and the entry regulation variables. In these columns, we use a General Least Squares model and allow for the error term to follow an AR(1) process. The results are robust to this alternative econometric specification as well. In columns 7 and 8, we allow for different time trends in the fraction of retail employment in each of the 95 départements. We find that the estimated entry regulation effect is also robust under this model. Finally, in columns 9 and 10, we investigate whether the entry variables are capturing other policy changes specifically targeted towards the less skilled. We do this by asking whether employment in hotels and restaurants, another industrial sector with a high proportion of low wage workers, is also significantly affected by the entry regulation variables. We replicate the basic regressions presented in Table 5 but now use the fraction of employment in hotels and restaurants as the dependent variable. The impact of the entry regulation variables on employment in hotels and restaurants is neither economically nor statistically significant.

The evidence we have put together so far is consistent with the idea that entry regulation had deleterious effects on employment rates in the French retail industry. We have not yet asked whether the composition of employment was affected as well. Table 9 investigates such compositional effects. We concentrate on 4 aspects of retail employment: the fraction of people working in small retail stores (9 people or less), the fraction of salaried retail workers, the fraction of part-time retail workers, and the average age of retail workers. For ease of presentation, we again focus on the 15-year stock measures. 
Recall that the original official motivation behind the Loi Royer was to protect small mom-and-pop stores from the rapid growth of larger retail establishments. Our findings in Table 9 confirm that entry regulation helps protect small retailers market share. We find that the fraction of people working in stores of less than 9 workers is negatively affected by increases both in the stock and the fraction of authorizations. A 1 percent increase in the stock of authorized stores reduces the fraction of people working in small stores by .03 percentage point. Interestingly, we also find that this effect is stronger in départements where fewer people live in large cities (cities of more than 200 thousands people). ${ }^{30}$ Small retailers thus appear to have an easier time maintaining themselves in more urban environments.

Column 3 shows that the fraction of salaried workers in retail trade increases with the stock of authorized stores. A 1 percent increase in the stock of authorized stores increases the fraction of workers that are salaried by .01 percentage point. This finding however does not seem robust to using the fraction of authorizations as an alternative measure of entry regulation (column 4). Interestingly, we find that the fraction of part-time workers goes up when entry in the retail sector is less intensely regulated. A 1 percent increase in the stock of authorized stores increases the fraction of part-time work in retail by .01 percentage point. Finally, we find no consistent effect of entry regulation on the average age of the people employed in retail trade.

\section{The Politics of Entry Regulation: An Instrumentation Strategy}

In the empirical specifications so far, we have assumed that the number of applications submitted to the zoning boards was not endogenous to the entry regulation process itself. Instead, we have assumed that the number of new applications each year simply vary with the quality of the economic environment for retail businesses in that year. If the application process is costly to store promoters,

\footnotetext{
${ }^{30}$ These regressions are not reported here but are available from the authors upon request.
} 
however, one might expect the number of new applications to fluctuate with the expected stringency of the zoning board. For given economic conditions, fewer promoters will be willing to apply when they expect a low probability of approval. A high rate of approval may therefore not reflect zoning board leniency but rather a low level of applications, with the self-selection of a group with high approval probabilities. This possible endogeneity of applications will generate a downward bias in the size of the entry regulation effect we have estimated so far. In this section, we try to get around this problem by isolating a source of variation in authorizations that is solely related to the intensity of entry regulation. The instrumentation strategy we propose is based on the politics of entry regulation, a process of interest in its own right. The instrumentation strategy allows us to identify the effect of entry regulation without having to rely directly on applications.

As we mentioned earlier, the membership composition of zoning boards is such that the median voter is likely to be an elected politician. Recall that out of twenty voting members in each zoning commission, nine are shopkeepers and craftsmen's representatives (and seven of those self-employed), two are consumer representatives, and the rest are locally elected politicians. Given that consumer representatives are typically in favor of entry, shopkeepers will need the support of at least some politicians to prevent entry. One might therefore expect political representation in a given département and a given year to effect the level of entry regulation in that département and year.

In fact, some further institutional knowledge might help us hypothesize about which political parties are most opposed to the entry of large retail stores. In its original spirit, the Loi Royer was introduced as a way to protect small shopkeepers from larger competitors. One might thus expect the political parties who get a disproportionate share of small shopkeepers' votes to be the strongest opponents to the creation of new large stores. As these parties try to maintain the political support of this group of electors, they may use their influence on the boards to limit entry. 
In a book called "La Boutique Contre La Gauche" ("The Boutique Against the Left"), Nonna Mayer (1986) undertook a thorough investigation of the social and political behavior of small shopkeepers in France. She documents a strong political bias among small shopkeepers towards non-extremist rightwing parties. More specifically, she shows that the UDF ("Union pour la Démocratie Française") and the RPR ("Rassemblement Pour la République"), the two largest right-wing parties in France, receive a disproportionate fraction of shopkeepers' votes. Such a preference for right-wing parties, Mayer comments, is rather typical among the self- employed. The self-employed typically assume that left-wing parties such as the PS ("Parti Socialiste) will rather protect the interest of salaried workers (Mayer, 1986).

Hence, in theory at least, a good predictor of the authorization of new retail space in a given département in a given year is the political representation in that département and year. More elected politicians coming from the right of the political spectrum would imply that the median board member is more likely to be someone opposed to entry; more elected politicians coming from the left of the political spectrum would imply that the median board member is more likely to be someone in favor of entry. In practice, we will use the results of national elections to the Assemblée Nationale, France's main legislative body, to measure the representation of political parties by département. ${ }^{31}$

Although we have just argued that political representation may generate variation in entry by affecting the preference of the median voter on the zoning boards, we further need to justify why political representation may not be correlated with other determinants of retail employment. Political business cycles could be one source of concern. If shocks to retail employment correlate with general employment shocks in a département and election results correlate with these general employment shocks, this might induce a correlation between retail employment and political representation. ${ }^{32}$ It is

\footnotetext{
${ }^{31}$ The election data is presented in section A1.

${ }^{32}$ Recall however that we control for the regional unemployment rate in all of our specifications.
} 
however difficult to see how shocks specific to retail might affect election results. Because we investigate the impact of entry regulation not only on the level but also on the fraction of retail employment, we do not believe that political business cycles are an important issue.

In addition, because of the construction lag, it is the stock of stores authorized up to four years prior to the current year, and hence the political representation up to four years prior to the current year, that should affect current retail employment through the entry regulation process. Current political representation is not part of the identification. The presence of a construction lag also weakens the argument that political representation is capturing policies other than zoning. Any other decision taken by local politicians to affect retail employment, such as increasing local taxes, will very likely take less than four years to get implemented. ${ }^{33}$ An increase in local taxes, for example, should have rather immediate effects on the rate of exit of firms or on their hiring and firing decisions. Moreover, we will be able to control for current and one-year lagged political representation in a département to capture any such recent policy changes.

\subsection{Results}

Table 10 presents the first-stage regressions. Table 10 confirms that political representation in a département is a strong determinant of authorizations. The dependent variables in columns 1 to 3 are the logarithm of the total stock, 15-year stock and 10-year stock of authorized stores until $(t-4)$, respectively. We construct the political instruments accordingly. For example, Fraction PS in column 1 is the cumulated fraction of votes going to the Socialist party from the inception of the Loi Royer until $(t-4)$. All regressions include, in addition to the political variables, year fixed effects, département fixed effects and the vector $X_{i t}$ of time-varying département characteristics. The missing category

\footnotetext{
${ }^{33}$ Moreover, as we already mentioned, local politicians in France have only very limited policy discretion. In that sense, the decentralization of the zoning regulation is rather exceptional.
} 
among the political variables is the fraction of abstentions and nul votes.

We find that the Green party has the most negative influence on the stock of authorized retail space. One interpretation of this finding is that the Green party might be especially concerned about the environmental impact of new constructions in often rather rural settings. Of special interest to us is the contrast between the UDF and RPR, the two major parties on the right-wing of the political spectrum and the parties small shopkeepers are the most likely to support, and the PS, the major party on the left-wing of the political spectrum. ${ }^{34}$ Consider column, 2 for example. The RPR and UDF have a small and statistically insignificant impact on the stock of authorized retail space. Only the estimated effect for the Green party is smaller than that for the RPR and UDF. On the other hand, an increase in PS representation has the most positive impact on the growth of authorized retail space in a département. The difference between the estimated effects for PS and RPR-UDF representation is statistically significant. All the other, smaller, parties cannot be statistically differentiated with respect to their effect on entry regulation. Finally, note that the political variables are jointly very significant for each of the first-stage regressions in Table 10 .

Table 11 displays the effect of entry regulation on retail employment in the IV model. Panel A uses the logarithm of employment in retail as a dependent variable, Panel B uses the fraction of total employment in retail. We present results for the 3 different depreciation schemes of the stock variables. We display both the OLS and IV results. All regressions include year fixed effects, département fixed effects and the usual vector of time-varying département characteristics. In all cases, we find a positive relationship between retail employment and the stock of authorized stores. The effects are two to three times larger in the IV specifications than in the OLS specifications. The IV results confirm that our OLS result are if anything likely to be biased downwards.

\footnotetext{
${ }^{34}$ Note that because the UDF and the RPR formed a coalition during some of the elections in the 1980s, we cannot systematically separate them in the empirical analysis.
} 
Table 12 investigates various tests of the robustness of the IV results. We show that controlling for either the current or one-year lagged political representation in the département (or both) does not affect the qualitative nature of our findings. Only in column 4, where we control only for the lagged political representation do we lose statistical significance. Finally, we also show that the fraction of employment in hotels and restaurants is not affected by politically-induced changes in the stock of authorized stores. This last result suggests that the instruments are unlikely to capture other policy changes targeted towards the bottom part of the wage distribution.

\section{Summary and Conclusion}

Our findings suggest that the zoning laws that were introduced in France in the early 1970s and that have since then restrained the creation and extension of large stores in the retail industry have had a negative impact on retail employment. Hence, the sluggish employment growth witnessed in the French retail sector over the last two or three decades may not only have been the result of labor market rigidities. Instead, product market regulation and barriers to entry appear to have played a significant role. Although the results in this paper are specific to a given industry in a given country, the lesson learned is of much more general interest. Specifically, countries fighting sluggish rates of job creation may be misguided in thinking that their employment problem will be fully solved once they have reformed their labor markets. Instead, in order to fully bolster employment growth, they may also have to eliminate entry regulation policies and other forms of product market restrictions.

We hope to extend this paper on several dimensions in the future. First, a careful and systematic study of profitability margins in the retail industry in the US and European countries would adequately complement the evidence we have put together so far. By the same token, a systematic investigation 
of the role the Loi Royer may play in explaining high markups in French retail stores is another interesting venue for future research. Second, while we have focused on the retail industry, product market restrictions have been placed on other industrial sectors and should deserve as much research attention. Finally, while we have shown that product market restrictions matter for job creation, they are not the only form of non-labor market distortions. For example, financial markets also operate under much more constraints in Europe than in the US. Studying whether capital market restrictions have also slowed down the rate of new firm creation and subsequent employment growth is also a priority for future research. 


\section{References}

Allain, Marie-Laure and Claire Chambolle, "Retailer's Buying Power in France," Institut National de la Recherche Agronomique Working Paper, July 1999.

Barro, Robert and Herschel Grossman, "A General Disequilibrium Model of Income and Employment," American Economic Review, March 1971.

Bertrand, Marianne, Pierre Biscourp, Séverine Haller and Francis Kramarz, "Dispersion des Prix de Vente au Détail, Hétérogénéité des Formes de Vente et Structure de la Concurrence: Une Analyse Empirique sur Données Individuelles," Mimeo, CREST, November 2000.

Blanchard, Olivier and Justin Wolfers, "The Role of Shocks and Institutions in the Rise of European Unemployment: The Aggregate Evidence," Economic Journal, March 2000.

Blanchard, Olivier and Franceso Giavazzi, "Macroeconomic Effects of Regulation and Deregulation in Goods and Labor Markets," Mimeo, MIT, January 2001.

Card, David, Francis Kramarz and Thomas Lemieux, "Changes in the Relative Structure of Wages and Employment: A Comparison of the United States, Canada, and France," National Bureau of Economic Research Working Paper no. 5487, 1996.

Djankov, Simeon, Rafael La Porta, Florencio Lopez-de-Silanes and Andrei Shleifer, "The Regulation of Entry," National Bureau of Economic Research Working Paper no. 7892, 2000.

Dobson, Paul and Michael Waterson, "Retailer Power: Recent Developments and Policy Implications," with discussion, Economic Policy, April 1999.

Gersbach, Hans, "Promoting Product Market Competition to Reduce Unemployment in Europe: An Alternative Approach?", Kyklos, 2000.

Insee, "Les Entreprises du Commerce en 1997," Insee Résultats, 176, 2000, 158 pages. 
Krueger, Alan and Jorn-Steffen Pischke, "Observations and Conjectures on the U.S. Employment Miracle," National Bureau of Economic Research Working Paper no. 6146, 1997.

McKinsey Global Institute, Employment Performance, Washington, D.C.: McKinsey\&Company, 1994.

McKinsey Global Institute, Supprimer les Entraves à la Croissance et à l'EmpLoi en France et en Allemagne, Washington, D.C.: McKinsey\&Company, 1997.

Mayer, Nonna, La Boutique Contre La Gauche, Paris: Presses de la Fondation Nationale des Sciences Politiques, 1986.

Ministère de l'Industrie, du Commerce et de l'Artisanat, Loi D'Orientation du Commerce et de l'Artisanat, 1974.

Nickell, Stephen and Richard Layard, "Labour Market Institutions and Economic Performance," in Orley Ashenfelter and David Card, eds, The Handbook of Labor Economics, Amsterdam: North Holland, 1999.

Piketty, Thomas, "Les Créations d'Emploi en France et aux Etats-Unis: 'Services de Proximité Contre 'Petits Boulots'," Notes de la Fondation Saint-Simon, 1997.

Pashigian, Peter, "Contracts, Externalities and Incentives in Shopping Malls: An Empirical Analysis," University of Chicago Graduate School of Business Working Paper, 1997. 
Table 1

Long Term Employment Trends in France and US ${ }^{a}$

\section{France}

\begin{tabular}{lcc} 
& $\begin{array}{c}\text { Retail and } \\
\text { Wholesale Trade }\end{array}$ & $\begin{array}{c}\text { Hotels and } \\
\text { Restaurants }\end{array}$ \\
Year: & & \\
1896 & 5.5 & 2.3 \\
1906 & 6.9 & 2.7 \\
1954 & 10.3 & 2.7 \\
1973 & 13.2 & 2.7 \\
1982 & 13.8 & 2.8 \\
1989 & 13.8 & 3.2 \\
1996 & 13.6 & 3.5 \\
& & \\
\hline \hline
\end{tabular}

\section{United States}

\begin{tabular}{lcc} 
& $\begin{array}{c}\text { Retail and } \\
\text { Wholesale Trade }\end{array}$ & $\begin{array}{c}\text { Hotels and } \\
\text { Restaurants }\end{array}$ \\
Year: & & \\
1900 & 6.9 & 2.8 \\
1930 & 12.6 & 3.1 \\
1950 & 15.9 & 3.1 \\
1960 & 17.1 & 3.6 \\
1972 & 17.9 & 4.7 \\
1980 & 17.4 & 5.6 \\
1988 & 17.5 & 6.2 \\
1996 & 17.5 & 6.6 \\
\hline
\end{tabular}

${ }^{a}$ Notes:

1. From Piketty, 1997. Sources: various censuses and INSEE computation for France (upper panel); various censuses and CPS for US (lower panel).

2. Each observation in the table represents the fraction of total employment in the relevant industrial sector. 
Table 2

Recent Employment Trends in France (1975-1998) ${ }^{a}$

Panel A: Employment Share In:

Retail Food Retail Non-Food Retail Hotels and Restaurants Other Services

$\begin{array}{cccccc}\text { Year Trend*100 } & -0.028 & -0.005 & -0.023 & 0.019 & 0.082 \\ & (0.004) & (0.003) & (0.003) & (0.003) & (0.007)\end{array}$

$\begin{array}{llllll}\text { Adjusted } \mathrm{R}^{2} & 0.388 & 0.329 & 0.340 & 0.487 & 0.547\end{array}$

\begin{tabular}{lccccc}
\hline \hline \multicolumn{5}{c}{ Panel B: Log(Employment) In: } \\
& Retail & Food Retail & Non-Food Retail & Hotels and Restaurants & Other Services \\
& & & & 1.376 & \\
Year Trend*100 & 0.259 & 0.452 & 0.135 & $(0.111)$ & 1.126 \\
& $(0.076)$ & $(0.101)$ & $(0.091)$ & $.060)$ \\
Adjusted $\mathrm{R}^{2}$ & .894 & .809 & .869 & .934 \\
& & & & & \\
\hline \hline
\end{tabular}

${ }^{a}$ Notes:

1. Source: French Labor Force Surveys, 1975 to 1998.

2. The dependent variable in each column is the fraction of total employment (Panel A) or the logarithm of employment (Panel B) in the relevant industrial sector (by département and year).

3. Each regression includes département fixed effects. Observations are weighted by the total population in the département-year cell. 
Table 3

Distribution of Applications and Authorizations by City (1975-1998) ${ }^{a}$

\begin{tabular}{lccccc}
\hline \hline $\begin{array}{l}\text { No. of Applications } \\
\text { In a City }\end{array}$ & No. of Cities & Cumulated \% & $\begin{array}{c}\text { No. of Authorizations } \\
\text { In a City }\end{array}$ & No. of Cities & Cumulated \% \\
& & & & & \\
1 & 1263 & 45.4 & 0 & 765 & 27.4 \\
2 & 567 & 65.8 & 1 & 1256 & 72.6 \\
3 & 333 & 77.7 & 2 & 453 & 88.9 \\
4 & 196 & 84.8 & 4 & 163 & 94.8 \\
5 and More & 423 & 100 & 5 and More & 60 & 100 \\
&
\end{tabular}

${ }^{a}$ Notes:

1. Source: DECAS "Authorization Files," 1975 to 1998.

2. This data cover the food retail sector only. 
Table 4

Effect of Common Brand Name Between Incumbent and Applicant on Probability of Authorization ${ }^{a}$

\begin{tabular}{lcc}
\hline \hline & Share of Yes Votes & The Store is Authorized \\
Dependent Variable: & .046 & .046 \\
Applicant and Incumbent & $(.016)$ & $(.029)$ \\
With Same Brand Name & -.055 & -.061 \\
Size of Application & $(.006)$ & $(.010)$ \\
(in ln square meters) & .009 & .008 \\
$\begin{array}{l}\text { Stock of Previously Authorized Stores } \\
\text { (in ln square meters) }\end{array}$ & $(.005)$ & $(.009)$ \\
Adjusted R & & .161 \\
Number of Observations & .270 & 2721 \\
\hline \hline
\end{tabular}

${ }^{a}$ Notes:

1. Source: DECAS "Authorization Files," 1975 to 1998.

2. The data covers the food retail sector only.

3. The sample is the set of applications for which there is already an incumbent supermarket or megastore in place in the desired city of entry.

4. All regressions also include year fixed effects, département fixed effects, a vector of dummies for the incumbent's brand name, a vector of dummies for the applicant's brand name, and a dummy variable for whether the application concerns the creation of a new store or the extension of an existing store. 
Table 5

Effect of Zoning on Retail Employment:

Basic Results ${ }^{a}$

\begin{tabular}{|c|c|c|c|c|c|c|}
\hline \multicolumn{7}{|c|}{ Panel A } \\
\hline \multicolumn{7}{|c|}{ Dependent Variable: Ln(Retail Employment) } \\
\hline $\begin{array}{l}\text { Stock of Authorized Stores }(t-4) \\
\text { (in ln square meters) }\end{array}$ & $\begin{array}{l}.056 \\
(.014)\end{array}$ & - & - & - & - & - \\
\hline Fraction of Stores Authorized $(t-4)$ & - & $\begin{array}{l}.158 \\
(.044)\end{array}$ & - & - & - & - \\
\hline $\begin{array}{l}\text { 15-Year Stock of Authorized Stores }(t-4) \\
\text { (in ln square meters) }\end{array}$ & - & - & $\begin{array}{c}.053 \\
(.0133)\end{array}$ & - & - & - \\
\hline 15-Year Fraction of Stores Authorized $(t-4)$ & - & - & - & $\begin{array}{c}.151 \\
(.043)\end{array}$ & - & - \\
\hline $\begin{array}{l}\text { 10-Year Stock of Authorized Stores }(t-4) \\
\text { (in ln square meters) }\end{array}$ & - & - & - & - & $\begin{array}{c}.042 \\
(.011)\end{array}$ & - \\
\hline 10-Year Fraction of Stores Authorized $(t-4)$ & - & - & - & - & - & $\begin{array}{l}.133 \\
(.038)\end{array}$ \\
\hline Adjusted $\mathrm{R}^{2}$ & .936 & .936 & .936 & .936 & .936 & .936 \\
\hline
\end{tabular}

\section{Panel B}

Dependent Variable: Fraction of Employment in Retail

Stock of Authorized Stores $(t-4)$

(in ln square meters)

Fraction of Stores Authorized $(t-4)$

$(.001)$

15-Year Stock of Authorized Stores $(t-4)$

(in ln square meters)

15-Year Fraction of Stores Authorized $(t-4)$

10-Year Stock of Authorized Stores $(t-4)$

(in ln square meters)

10-Year Fraction of Stores Authorized $(t-4)$

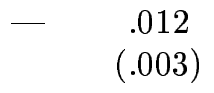

$-\quad-\quad .003$

$(.001)$

$-\quad-\quad .011$

Adjusted $\mathrm{R}^{2}$

.451

.451

$.441 \quad .449$

.010

(.002)

${ }^{a}$ Notes:

1. Source: French LFS and DECAS “Authorization Files," 1975 to 1998.

2. All regressions also include the stock of applications up to year (t-1) (all years, last 15 years or last 10 years), year fixed effects, département fixed effects, the unemployment rate, and a vector of variables for the age distribution and city size distribution in the département and year (see text for details).

3. Observations are weighted by the total population in the département-year cell.

4. Standard errors are in parentheses. 
Table 6

Effect of Zoning on Food Retail Employment:

Basic Results ${ }^{a}$

\section{Panel A}

Dependent Variable: Ln(Food Retail Employment)

\begin{tabular}{|c|c|c|c|c|c|c|}
\hline $\begin{array}{l}\text { Stock of Authorized Food Stores }(t-4) \\
\text { (in ln square meters) }\end{array}$ & $\begin{array}{c}.112 \\
(.017)\end{array}$ & - & - & - & - & - \\
\hline Fraction of Food Stores Authorized $(t-4)$ & - & $\begin{array}{l}.178 \\
(.063)\end{array}$ & - & - & - & - \\
\hline $\begin{array}{l}\text { 15-Year Stock of Authorized Food Stores }(t-4) \\
\text { (in ln square meters) }\end{array}$ & - & - & $\begin{array}{l}.088 \\
(.016)\end{array}$ & - & - & - \\
\hline 15-Year Fraction of Food Stores Authorized $(t-4)$ & - & - & - & $\begin{array}{l}.176 \\
(.061)\end{array}$ & - & - \\
\hline $\begin{array}{l}\text { 10-Year Stock of Authorized Food Stores }(t-4) \\
\text { (in ln square meters) }\end{array}$ & - & - & - & - & $\begin{array}{c}.074 \\
(.015)\end{array}$ & - \\
\hline 10-Year Fraction of Food Stores Authorized $(t-4)$ & - & - & - & - & - & $\begin{array}{c}.164 \\
(.054)\end{array}$ \\
\hline Adjusted $\mathrm{R}^{2}$ & .858 & .856 & .859 & .856 & .858 & .857 \\
\hline
\end{tabular}

Panel B

Dependent Variable: Fraction of Employment in Food Retail

Stock of Authorized Food Stores $(t-4)$

(in ln square meters)

Fraction of Food Stores Authorized $(t-4)$

15-Year Stock of Authorized Food Stores $(t-4)$

(in ln square meters)

15-Year Fraction of Food Stores Authorized $(t-4)$

.002

$(.0005)$

.004
$(.002)$

10-Year Stock of Authorized Food Stores $(t-4)$

(in ln square meters)

10-Year Fraction of Food Stores Authorized $(t-4)$

Adjusted $\mathrm{R}^{2}$

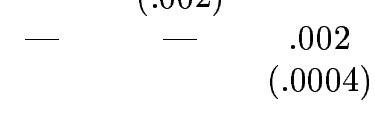

-004
$-\quad(.002)$

$-\quad-\quad-\quad \begin{array}{lll}.002 \\ (.0004)\end{array}$

.004

$(.001)$

$\begin{array}{lllllll}.383 & .354 & .368 & .354 & .357 & .354\end{array}$

${ }^{a}$ Notes:

1. Source: French LFS and DECAS “Authorization Files," 1975 to 1998.

2. All regressions also include the stock of applications in food retail up to year ( $t-1)$ (all years, last 15 years or last 10 years), year fixed effects, département fixed effects, the unemployment rate, and a vector of variables for the age distribution and city size distribution in the département and year (see text for details).

3. Observations are weighted by the total population in the département-year cell.

4. Standard errors are in parentheses. 
Table 7

Effect of Zoning on Non-Food Retail Employment:

Basic Results ${ }^{a}$

\section{Panel A}

Dependent Variable: Ln(Non-Food Retail Employment)

Stock of Authorized Non-Food Stores $(t-4)$

(in ln square meters)

Fraction of Non-Food Stores Authorized $(t-4)$

15-Year Stock of Authorized Non-Food Stores $(t-4)$

(in ln square meters)

15-Year Fraction of Non-Food Stores Authorized $(t-4)$

10-Year Stock of Authorized Non-Food Stores $(t-4)$

(in ln square meters)

10-Year Fraction of Non-Food Stores Authorized $(t-4)$

.023

.150
$-\quad .051)$

$(.051)$
$-\quad-\quad .023$

$(.017)$

$\begin{array}{llll}- & - & - & .144 \\ - & - & - & (.049)\end{array}$

$\begin{array}{ccccc}- & - & - & - & .010 \\ - & - & - & - & (.014)\end{array}$

.111

$(.044)$

Adjusted $\mathrm{R}^{2}$

$\begin{array}{llll}.909 & .909 & .909 & .909\end{array}$

.909

\section{Panel B}

Dependent Variable: Fraction of Employment in Non-Food Retail

Stock of Authorized Non-Food Stores $(t-4)$

(in ln square meters)

Fraction of Non-Food Stores Authorized $(t-4)$

15-Year Stock of Authorized Non-Food Stores $(t-4)$

(in ln square meters)

15-Year Fraction of Non-Food Stores Authorized $(t-4)$

10-Year Stock of Authorized Non-Food Stores $(t-4)$

(in ln square meters)

10-Year Fraction of Non-Food Stores Authorized $(t-4)$
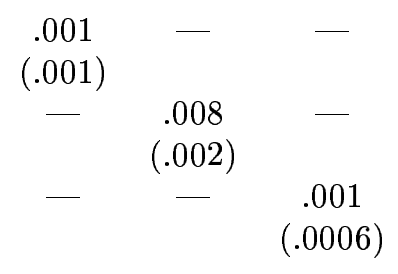

$\begin{array}{cccc}- & - & - & .008 \\ - & - & - & (.002)\end{array}$

-0003
$-\quad-0005)$

$\begin{array}{rrrr}- & - & - & .006 \\ & & (.002)\end{array}$

Adjusted $\mathrm{R}^{2}$

.393

.392

.393

.392

.392

.391

${ }^{a}$ Notes:

1. Source: French LFS and DECAS “Authorization Files," 1975 to 1998.

2. All regressions also include the stock of applications in non-food retail up to year (t-1) (all years, last 15 years or last 10 years), year fixed effects, département fixed effects, the unemployment rate, and a vector of variables for the age distribution and city size distribution in the département and year (see text for details).

3. Observations are weighted by the total population in the département-year cell.

4. Standard errors are in parentheses. 
Table 8

Effect of Zoning on Retail Employment:

Robustness Checks ${ }^{a}$

Dependent Variable: Fraction of Employment in: Retail

Hotels and Rest.

\begin{tabular}{|c|c|c|c|c|c|c|c|c|c|c|}
\hline $\begin{array}{l}\text { 15-Year Stock of Author. Stores }(t-4) \\
\text { (in ln square meters) }\end{array}$ & $\begin{array}{c}.004 \\
(.001)\end{array}$ & - & $\begin{array}{l}.003 \\
(.001)\end{array}$ & - & $\begin{array}{l}.002 \\
(.001)\end{array}$ & - & $\begin{array}{l}.002 \\
(.001)\end{array}$ & - & $\begin{array}{l}.0002 \\
(.0006)\end{array}$ & - \\
\hline 15-Year Frac. of Stores Author. $(t-4)$ & - & $\begin{array}{l}.013 \\
(.003)\end{array}$ & - & $\begin{array}{l}.009 \\
(.003)\end{array}$ & - & $\begin{array}{l}.008 \\
(.003)\end{array}$ & - & $\begin{array}{l}.008 \\
(.003)\end{array}$ & - & $\begin{array}{l}.003 \\
(.002)\end{array}$ \\
\hline $\begin{array}{l}\text { 15-Year Stock of Author. Stores }(t+1) \\
\text { (in ln square meters) }\end{array}$ & $\begin{array}{l}-.001 \\
(.001)\end{array}$ & - & - & - & - & - & - & - & - & - \\
\hline 15-Year Frac. of Stores Author. $(t+1)$ & - & $\begin{array}{l}-.003 \\
(.004)\end{array}$ & - & - & - & - & - & - & - & - \\
\hline Frac. of Emp. in Retail $(t-1)$ & - & - & $\begin{array}{l}.436 \\
(.022)\end{array}$ & $\begin{array}{c}.441 \\
(.022)\end{array}$ & - & - & - & - & - & - \\
\hline GLS (AR1) & no & no & no & no & yes & yes & no & no & no & no \\
\hline Département F.E.*Year & no & no & no & no & no & no & yes & yes & no & no \\
\hline Adjusted $\mathrm{R}^{2}$ & .454 & .445 & .566 & .562 & - & - & .520 & .514 & .539 & .538 \\
\hline
\end{tabular}

\footnotetext{
${ }^{a}$ Notes:

1. Source: French LFS and DECAS "Authorization Files," 1975 to 1998.

2. All regressions also include the stock of applications up to year (t-1) (15-year stock), year fixed effects, département fixed effects, the unemployment rate, and a vector of variables for the age distribution and city size distribution in the département and year (see text for details).

3. Observations are weighted by the total population in the département-year cell.

4. Standard errors are in parentheses.
} 
Table 9

Effect of Zoning on the Marginal Retail Worker ${ }^{a}$

\begin{tabular}{|c|c|c|c|c|c|c|c|c|}
\hline Dependent Variable: & \multicolumn{2}{|c|}{$\%$ Small Firms } & \multicolumn{2}{|c|}{$\%$ Salaried } & \multicolumn{2}{|c|}{$\%$ Part-Time } & \multicolumn{2}{|c|}{ Av. Age } \\
\hline $\begin{array}{l}\text { 15-Year Stock of Author. Food Stores }(t-4) \\
\text { (in ln square meters) }\end{array}$ & $\begin{array}{l}-.029 \\
(.007)\end{array}$ & - & $\begin{array}{c}.012 \\
(.006)\end{array}$ & - & $\begin{array}{l}.013 \\
(.004)\end{array}$ & - & $\begin{array}{l}-.222 \\
(.144)\end{array}$ & - \\
\hline 15-Year Frac. of Food Stores Author. $(t-4)$ & - & $\begin{array}{l}-.039 \\
(.022)\end{array}$ & - & $\begin{array}{l}-.006 \\
(.018)\end{array}$ & - & $\begin{array}{l}.031 \\
(.013)\end{array}$ & - & $\begin{array}{l}.551 \\
(.447)\end{array}$ \\
\hline
\end{tabular}

${ }^{a}$ Notes:

1. Source: French LFS and DECAS "Authorization Files," 1975 to 1998.

2. All regressions also include the stock of applications in retail up to year t-1 (15year stock), year fixed effects, département fixed effects, the unemployment rate, and a vector of variables for the age distribution and city size distribution in the département and year.

3. Observations are weighted by the total population in the département-year cell.

4. Standard errors are in parentheses. 
Table 10

First-Stage Regressions:

Effect of Political Representation on Authorizations ${ }^{a}$

Dependent Variable: Stock of Authorized Stores

(in ln square meters)

Non-depreciated Stock 15-Year Stock 10-Year Stock

Fraction RPR-UDF

Fraction PS

Fraction Various Right

Fraction Various Left

Fraction Extreme-Right

Fraction Extreme-Left

Fraction Green Party

Adjusted $\mathrm{R}^{2}$

F-Stat. for the Nullity of Instruments

(p-value)
.12

(.10)

.48

(.11)

.48

$-.33$

.33

(.14)

.12

$-.46$

.918

18.03

(.000)
.14

(.10)

.60

(.12)

.34

(.11)

.26

(.15)

.34

.45

(.16)

.22

(.11)

.54

(.14)

$-.25$

$-.16$

(.25)

.855

.905

11.26

(.000)

${ }^{a}$ Notes:

1. Source: French LFS, DECAS "Authorization Files," and CEVIPOF Election Files, 1975 to 1998.

2. All regressions also include year fixed effects, département fixed effects, the unemployment rate, and a vector of variables for the age distribution and city size distribution in the département and year.

3. Observations are weighted by the total population in the département-year cell.

4. Standard errors are in parentheses. 
Table 11

Effect of Zoning on Retail Employment:

IV Results ${ }^{a}$

\begin{tabular}{|c|c|c|c|c|c|c|}
\hline \multicolumn{7}{|c|}{ Panel A } \\
\hline \multicolumn{7}{|c|}{ Dependent Variable: Ln(Retail Employment) } \\
\hline Specification: & OLS & IV & OLS & IV & OLS & IV \\
\hline $\begin{array}{l}\text { Stock of Authorized Stores }(t-4) \\
\text { (in ln square meters) }\end{array}$ & $\begin{array}{l}.057 \\
(.013)\end{array}$ & $\begin{array}{l}.140 \\
(.046)\end{array}$ & - & - & - & - \\
\hline $\begin{array}{l}\text { 15-Year Stock of Authorized Stores }(t-4) \\
\text { (in ln square meters) }\end{array}$ & - & - & $\begin{array}{l}.054 \\
(.011)\end{array}$ & $\begin{array}{l}.158 \\
(.047)\end{array}$ & - & - \\
\hline $\begin{array}{l}\text { 10-Year Stock of Authorized Stores }(t-4) \\
\text { (in ln square meters) }\end{array}$ & - & - & - & - & $\begin{array}{l}.044 \\
(.011)\end{array}$ & $\begin{array}{l}.143 \\
(.046)\end{array}$ \\
\hline Adjusted $\mathrm{R}^{2}$ & .936 & - & .936 & - & .936 & - \\
\hline
\end{tabular}

Panel B

Dependent Variable: Fraction of Employment in Retail

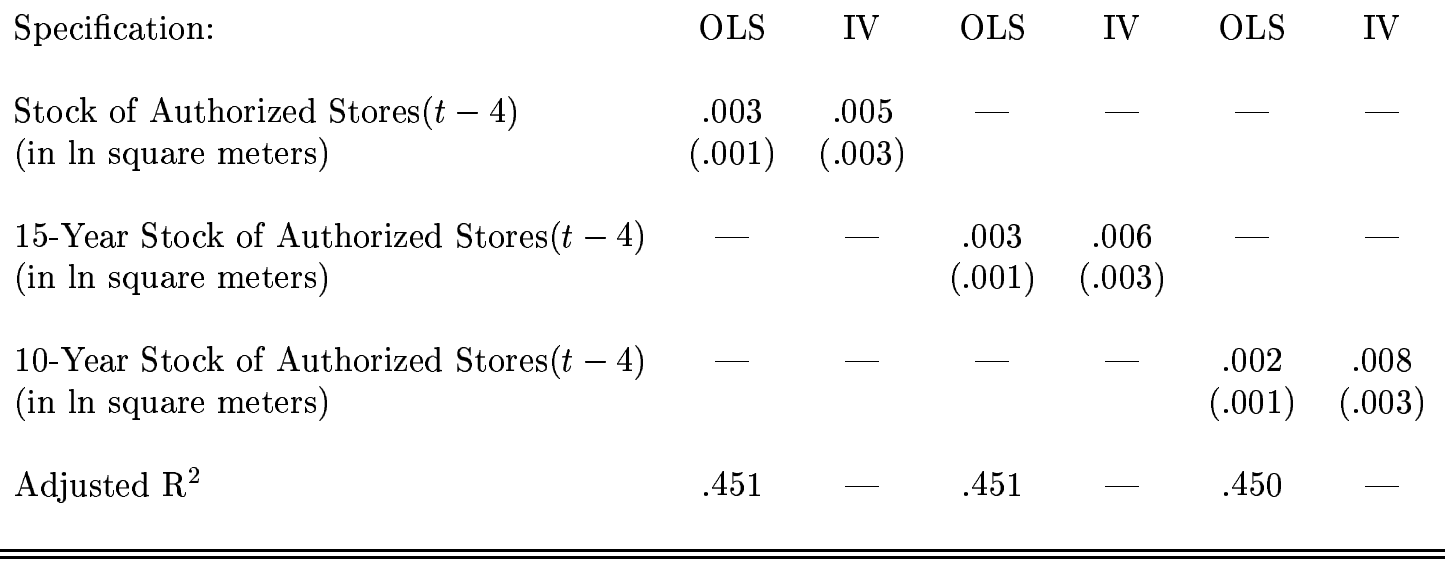

${ }^{a}$ Notes:

1. Source: French LFS and DECAS “Authorization Files," 1975 to 1998.

2. All regressions also include year fixed effects, département fixed effects, the unemployment rate, and a vector of variables for the age distribution and city size distribution in the département and year (see text for details).

3. Observations are weighted by the total population in the département-year cell.

4. Standard errors are in parentheses. 
Table 12

Effect of Zoning on Retail Employment:

IV Results

Robustness Checks ${ }^{a}$

Dependent Variable: Fraction of Employment in:

Retail

Hotels and Rest.

\begin{tabular}{lcccccccc} 
Specification: & OLS & IV & OLS & IV & OLS & IV & OLS & IV \\
$\begin{array}{l}\text { 15-Year Stock of Author. Stores }(t-4) \\
\text { (in ln square meters) }\end{array}$ & .003 & .006 & .003 & .004 & .003 & .005 & -.000 & .001 \\
Political Representation $(t)$ & $(.001)$ & $(.003)$ & $(.001)$ & $(.003)$ & $(.001)$ & $(.003)$ & $(.001)$ & $(.002)$ \\
Political Representation $(t-1)$ & yes & yes & no & no & yes & yes & no & no \\
Adjusted R $\mathrm{R}^{2}$ & no & no & yes & yes & yes & yes & no & no \\
\hline \hline
\end{tabular}

${ }^{a}$ Notes:

1. Source: French LFS and DECAS “Authorization Files," 1975 to 1998.

2. All regressions also include year fixed effects, département fixed effects, the unemployment rate, and a vector of variables for the age distribution and city size distribution in the département and year (see text for details).

3. Observations are weighted by the total population in the département-year cell.

4. Standard errors are in parentheses. 


\section{Appendix A1: Data Description}

\section{Labor Force Data}

In March of every year the French statistical institute (INSEE) conducts a Labor Force Survey (LFS). The LFS is a household survey. Each individual in a household is asked a set of standard questions that are repeated in every LFS. Roughly 60,000 households are interviewed every year. In particular, we know each individual's départment of residence. We restrict our attention to all so-called "département de France Métropolitaine," i.e. we exclude the Antilles, La Réunion and other maritime provinces. We, however, include Corsica in the analysis. There are 95 such départments. We use the LFS for the years

1975 to 1998 . Although the structure of the questionnaire changed in 1975, 1982, and 1990, most variables of interest are available across survey years.

For each year and départment, we construct stocks and averages for a set of demographic and labor market variables of interest: total population, an age structure vector (20 years old and less, from 21 to 40, from 41 to 60 , above 60 ), an education structure vector (8 education groups), a city structure vector (the share of persons leaving in rural areas, in cities with less than 20,000 inhabitants, in cities between 20,000 and 200,000 inhabitants, and in cities with more than 200,000 inhabitants), the employment rate and the unemployment rate.

Of central importance to us is employment in the retail sector and other low wage sectors. Using a 4-digit industry code (the Nomenclature d'Activités et de Produits -NAP- up to 1992 and the Nomenclature d'Activités Française -NAF- starting in 1993), we measure, for each département and year cell, employment in food retail, non-food retail, hotels and restaurants, and other low-wage services. It is important to note that employment in retail includes all individuals that report working in that sector, whether they report positive earnings or not. For example, the wife of a self-employed retailer that 
"helps" in the store will be included.

Finally, for both the entire département and the various industrial sectors described above, we also construct a set of other labor market characteristics: fraction of low wage workers, fraction of parttime workers, fraction of self-employed, fraction of salaried workers, and fraction of workers employed in firms with 9 employees or less.

Appendix A2 presents means and standard deviations for the main variables of interest in the LFS extracts. The unit of observation is the département/year cell. The data covers the time period 1975 to 1998. The average employment rate over that time period in France is about $50 \%$. More than a quarter of French people live in rural areas and about $22 \%$ of them are over 60 years old. Employment in retail food accounts for slightly more than $3 \%$ of total employment while $4.5 \%$ of people are employed in non-food. $35 \%$ of total employment occurs in establishments with 9 employees or less.

The two lower panels of Appendix A2 describes in more detail the French retail industry (both food and non-food). Not surprisingly, women are over-represented in retail activities. While female workers account for only about $43 \%$ of total employment, the equivalent figures are 55 and $61 \%$ in food and non-food retail respectively. Self-employment is also much more prevalent in retail, especially in non-food retail where nearly a third of all workers are self-employed. There are more part-time workers in food (17\%) and non-food (15\%) retail than in the economy as a whole (11\%). Finally, average hourly wages are lower in retail trade, and especially in the food sector. In particular, the fraction of workers "at" the minimum wage (between 0.95 times the minimum and 1.1 times the minimum) is $16 \%$ in food retail, $12 \%$ in non-food, and only $8 \%$ in the entire working population. 


\section{The DECAS "Authorization Files"}

The "Direction du Commerce et de l'Artisanat" at the Ministry of Economics and Finance has maintained an exhaustive listing of all applications submitted to any zoning board since the inception of the Loi Royer. The records were kept on paper from 1975 to 1986 and in an electronic format thereafter.

For almost every application, DECAS records the name of the applicant, size of the store (in square meters), specialty of the store (food or non-food with varying details depending on the year), the location of the store (départment and city), terms of the application (whether seeking to create or expand a previously existing store), and the outcome of the commission vote (an indicator for whether the store was authorized or rejected, as well as the number of "yes" votes, number of "no" votes, and number of abstentions).

We created an electronic version of the 1975 to 1986 files and then constructed the following variables: for each year, each départment, and three different retail categories (food retail, non-food retail and the aggregation of both food and non-food), we computed the total space promoters applied for (in square meters), and the space that was approved (in square meters). Starting with these annual flow variables, we then computed the stock of applications and approvals in a year/département/retail category cell by respectively summing all the applications and authorizations in that département/retail category cell from 1975 to that year. We also computed the stock of applications and authorizations over the last 15 years and the last 10 years. Such a simple deflation technique aims at accounting

for the depreciation of the retail capital stock. Finally, we computed the fraction of stores authorized (ratio of the stock of authorized stores to the stock of applications) over these 3 time frames. 


\section{The CEVIPOF Election Files}

The "Centre d'Etudes de la Vie Politique Française" is a research institute that focuses on the political practices of French citizens. It maintains a data base on all national elections to the Assemblée Nationale, France's main legislative body. The CEVIPOF records the breakdown of votes by département for each of the major French political parties. From the right to the left of the political spectrum, these major political parties are: the "Extreme Droite," various small right-wing parties labelled as "Divers Droites," the "Rassemblement Pour la République" (RPR , and its other denominations in various election years), the "Union pour la Démocratie Française" (UDF, and its other denominations in the various election years), the "Parti Socialiste" (PS, and its other denominations in the various election years), other small left-wing parties labelled as "Divers Gauches," and the "Extreme Gauche," which mostly accounts for the communist party. Finally, the data also isolates the Green Party as an independent entity. In our empirical strategy, we will group together the two major right-wing parties in France, UDF and RPR. These two parties indeed formed a coalition during some of the elections of the 1980 s and cannot be systematically separated over the period under study.

Legislative elections in France typically have two rounds. Under French voting law, only the subset of political parties that have performed well enough in the first round are allowed to stay on for the second round. In this paper, we will focus on the results of the first round since they best reflect voters' preferences in a given year and département. Elections took place in 1973, 1978, 1981, 1986, 1988, 1993 , and 1997. 
Appendix A2

Summary Statistics: LFS Data ${ }^{a}$

\begin{tabular}{|c|c|c|}
\hline Sample: & \multicolumn{2}{|c|}{ All Population } \\
\hline & Mean & St. Dev. \\
\hline \multicolumn{3}{|l|}{ Variable: } \\
\hline Employment Rate & 0.5017 & 0.0568 \\
\hline Fraction above 60 years old & 0.2260 & 0.0504 \\
\hline Fraction below 20 years old & 0.1122 & 0.0205 \\
\hline Fraction leaving in rural areas & 0.2689 & 0.1881 \\
\hline Sample: & \multicolumn{2}{|c|}{ All Employed } \\
\hline & Mean & St. Dev. \\
\hline \multicolumn{3}{|l|}{ Variable: } \\
\hline Fraction males & 0.5776 & 0.0402 \\
\hline Fraction self-employed & 0.1598 & 0.0735 \\
\hline Fraction in firms with 0 to 9 employees & 0.3553 & 0.1426 \\
\hline Fraction part-time & 0.1117 & 0.0380 \\
\hline Fraction in food retail & 0.0310 & 0.0101 \\
\hline Fraction in non-food retail & 0.0453 & 0.0128 \\
\hline Fraction in hotels and restaurants & 0.0306 & 0.0128 \\
\hline Fraction in other low wage services & 0.1144 & 0.0434 \\
\hline Fraction low-wage workers & 0.0808 & 0.0331 \\
\hline Sample: & \multicolumn{2}{|c|}{ Food Retail } \\
\hline & Mean & St. Dev. \\
\hline \multicolumn{3}{|l|}{ Variable: } \\
\hline Fraction males & 0.4527 & 0.1172 \\
\hline Fraction self-employed & 0.2364 & 0.1353 \\
\hline Fraction in firms with 0 to 9 employees & 0.4223 & 0.1804 \\
\hline Fraction part-time & 0.1719 & 0.1166 \\
\hline Fraction low-wage workers & 0.1638 & 0.1372 \\
\hline Sample: & \multicolumn{2}{|c|}{ Non-Food Retail } \\
\hline & Mean & St. Dev. \\
\hline Variable: & & \\
\hline Fraction males & 0.3898 & 0.0928 \\
\hline Fraction self-employed & 0.3125 & 0.1236 \\
\hline Fraction in firms with 0 to 9 employees & 0.6034 & 0.1618 \\
\hline Fraction part-time & 0.1571 & 0.0855 \\
\hline Fraction low-wage workers & 0.1165 & 0.1025 \\
\hline
\end{tabular}

${ }^{a}$ Notes:

1. Source: French Labor Force Surveys extracts, 1975 to 1998.

2. Each observation is a year-department cell.

3. Number of observations: 2,267 . 